\title{
European Citizenship Practice
}

\author{
Antje Wiener
}

Paper prepared for presentation at the European Union Studies Association (EUSA)

Tenth Biennial International Conference in Montreal, Quebec, Canada, May 17-May 19, $2007 .^{1}$

\section{Address}

Professor of Politics and International Relations

Department of European Studies and Modern Languages

University of Bath

BATH BA2 7AY

United Kingdom

Email: aw309@bath.ac.uk,.

\footnotetext{
${ }^{1}$ Another version of this paper is currently being published in Modern Citizenship. National Citizenship and the Debates in Citizenship Studies, ed Mueller, H P and J Mackert, VS Verlag (in German).
} 


\section{Introduction}

The process through which citizenship substance was established in the European Union $(E U)^{2}$ differs considerably from the social struggles that "forged" the institutions of the European nation-states in the $18^{\text {th }}$ and $19^{\text {th }}$ centuries. ${ }^{3}$ In the EU citizenship was established in a "top-down" fashion. ${ }^{4}$ In the light of this practice, the low key reputation of citizenship and more generally 'things constitutional' in the EU comes as little surprise. However, as this paper will demonstrate, once a broader socio-historical concept of citizenship is applied, it is possible to recover a composite set of practices including actors such as the Brussels political organs and the European Court of Justice (ECJ) as well as advocacy groups and single citizens have actually contributed to some quite substantial changes of citizenship across the Europolity. These changes include for example a shift in conditions of belonging e.g. from the 1913 ius sanguinis based citizenship law in Germany towards a more flexible ius solis based concept in 2000. ${ }^{5}$ They also involve expanded access to social citizenship rights based on the provisions for non-discrimination based on nationality (Art 13 TEU) in a number of cases. And, they involve a number of cases in which equal rights between men and women at the workplace were successfully established following court rulings.

When the ink of the Maastricht Treaty was barely dry the prevailing opinion amongst

\footnotetext{
${ }^{2}$ I will refer to the 'European Union (EU)' throughout, acknowledging that the correct legal terminology included the European Economic Communities (EEC) until the European Community (EC) and the European Union (EU) were introduced with the Maastricht Treaty.

${ }^{3}$ See e.g. Jenson 1992, Hobson 19xx, Wobbe 1998, Tilly 1996.

${ }^{4}$ See Turner's distinction of four models of citizenship including the top-down model of 'Bismarckian' citizenship (Turner 1990).

${ }^{5}$ Note, that this law excludes the possibility of dual citizenship for adults, however. Frankfurter Rundschau, 6 September 2005, p. 37 “144 Türken verlieren ihren deutschen Pass.”
} 
lawyers who had been involved in drafting the final text was that "we lawyers have done our job. We set the legal conditions and the treaty framework. It is now up to politics to take that concept further." ${ }^{6}$ And, indeed, this did happen for a while. Once Citizenship of the Union was legally stipulated with the 1993 Maastricht Treaty, politics appeared to pick up. Despite the considerably down-sized substance reflected in the minimalist treaty language, the insertion of a new citizenship discourse into a lexicon of Euro-speak that had, until then, famously been ridiculed for measuring the bend of bananas struck a new cord with the public. Now advocacy groups began requesting a more inclusive concept of citizenship. Most of these demands addressed enhanced citizenship rights for so-called third-country nationals.

However, despite such activities, there was never a broad-based movement engaged in EU citizenship policy. Instead, the ECJ began to intervene with "tactical interventions" and thus actively participated in the construction and expansion of Union citizenship rights based on its jurisprudence. ${ }^{7}$ This comes as a surprise in two regards. First, there seemed to be little room for constructive legal manoeuvre in the early 1990s. After all, the outcome of citizenship politics and policy was significantly thinned down compared to the normatively much more ambitious and politically considerably more creative plans developed in the two decades of citizenship practice preceding Maastricht. ${ }^{8}$ Secondly, new institutionalist scholarship had argued that as one of the EU's main organs the ECJ was under the member states' influence on 'their' respective judges at the court. ${ }^{9}$ The notable shift of influential actors on institutional and substantive change of Union citizenship towards the ECJ is hence

\footnotetext{
${ }^{6}$ Interview with former Commission official Dr Manfred Degen, summer 1993, Brussels.

${ }^{7}$ Kostakopoulou 2005, 235.

${ }^{8}$ See Wiener (1998, Chs 4-11) for details on the periods of citizenship politics and policy preceding Maastricht.

${ }^{9}$ Garrett 1992.
} 
quite remarkable. While at the time of the legal stipulation of citizenship in 1993 a long period of political influence on citizenship had been finalised by lawyers, and then handed back over to politicians. Now, more than a decade into the institutionalisation of citizenship in the EU, the ECJ appears to have gained some considerable weight in forging the substance of citizenship. Does the interplay between individual citizens and a supranational court therefore reflect a specifically 'European' ${ }^{10}$ substance of citizenship?

The paper elaborates on this question. I argue that, the change of influential actors does indeed reflect the particularity of citizenship in a non-state. The argument builds on other work on fragmented citizenship and citizens' rights in Europe and elsewhere. ${ }^{11}$ It sustains the notion of a new type of citizenship which is not only fragmented but also derived from a mixed set of practices. The following four sections elaborate on the development, conceptualisation and implications of such practice in the EU. Section two summarises citizenship facts and findings. Section three revisits the concept of citizenship practice and summarises the socio-historical approach. Section four presents legal and political accounts of citizenship practice in the EU. Section five proposes to expand this perspective’s theoretical tools.

\footnotetext{
${ }^{10}$ Note that when using the term European is used with an understanding that the wider Europe stretches beyond the boundaries of the European Union.

${ }^{11}$ This work involves new types of citizenship practice which evolve around the relation between individuals and supranational organs such as e.g. the European Court of Justice, the European Commission, or the European Convention of Human Rights or other. It includes Soysal's work on the concept of personhood, Benhabib's concept of reflexive iteration of the conditions of membership (Benhabib 2004), Fraser's concept of cultural recognition (Fraser 2005), and both Kostakopoulou's and Shaw's accounts of the changing terms of citizenship based on the interplay between citizens (as groups or individuals) and the European legislative institutions (Kostakopoulou 2005, Shaw 2006, in preparation).
} 


\section{European Citizenship: Facts, Fallacies and Findings}

While the EU is neither a state nor is it expected to turn into one in the future, European citizenship policy has always been linked to particular, albeit differing ways of thinking about the state. ${ }^{12}$ I label it 'beyond-the-state' citizenship as it involves politics and policy-making by states, in spite of states, and beyond state limits. The following summarises facts, fallacies and findings of European citizenship since Maastricht.

\subsection{Facts}

Citizenship of the Union was established by the Maastricht Treaty in 1991. Since the ratification of the Maastricht Treaty in November 1993, citizens of the European Union enjoy a number of rights that are directly conveyed by and enforceable through the EU. Union citizenship stipulates the following for all Union citizens: the right to move freely and to reside on the territory of the Member States (Art 18 TEC); the right to vote and to stand as a candidate in elections to the European Parliament and in municipal elections in the Member State in which he resides, under the same conditions as nationals of that State (Art 19 TEC); the right, in the territory of a third country in which his country is not represented, to protection by the diplomatic or consular authorities of another Member State, on the same conditions as the nationals of that State (Art 20 TEC); the right to petition the European Parliament (Art 21 TEC) and the right to apply to the ombudsman (Art 21 TEC) in order to bring to his attention any cases of poor administration by the Community institutions and bodies, with the exception of the legal bodies. It also means, following the entry into force of the Amsterdam Treaty the right to apply to the European institutions in one of the

\footnotetext{
${ }^{12}$ In the following, reference to Union citizenship will be made when indicating exclusive reference to the formal institutional parameters. In turn, reference to the wider concept will be indicated by the term European citizenship.
} 
official languages and to receive a reply in that language (Art 22 TEC); the right to have access to European Parliament, Council and Commission documents under certain conditions (Art 255 TEC). The last three rights also apply to natural or legal persons with their residence or headquarters in a member state.

Two further aspects deserve attention. First, the Amsterdam Treaty adds a distinctive line on the complementarity of European and national citizenship by stipulating that “[C]itizenship of the Union is hereby established. Every person holding the nationality of a Member State shall be a citizen of the Union. Citizenship of the Union shall complement and not replace national citizenship.” (Art 17 TEC, emph added AW) Secondly, there are a number of provisions in the Treaty of European Union (TEU) as well as in the Treaty Establishing the European Community (TEC) in addition to the citizenship Arts 17-22 TEC. These provisions relate either directly or indirectly to Union citizens. They involve for example Art 1 TEU (ever closer Union, decision taking close to citizens), Art 2 TEU (identity on international level, acquis communautaire), Art 6(1) TEU (principles of freedom, democracy, human rights, basic freedoms, rule of law), Art 6(2) TEU (fundamental rights ECHR, member state constitutions), Art 6(3) TEU (national identity of member states), Art 12 TEC (no discrimination on grounds of nationality), Art 14 TEC (space without internal frontiers), Art 39 TEC (free movement of workers), Art 141 TEC (equal pay for men and women). That is the citizenship acquis entails much more than the six designated ‘citizenship’ articles. ${ }^{13}$ Especially Arts 12 and 141 TEC have been most influential on the development of substantive citizenship in the EU. ${ }^{14}$ What do these provisions mean for the substantive development of European citizenship?

\footnotetext{
${ }^{13}$ For a comprehensive table, see Wiener 2001, 337 Table 16.1.

${ }^{14}$ See Caporaso 2000 and Kostakopoulou 2005, respectively.
} 


\subsection{Fallacies}

Ever since European citizenship policy sought to generate a firmer European identity in the early $1970 \mathrm{~s}^{15}$ the discussion about the lack of a demos, not to speak of an ethnos prevails. ${ }^{16}$ The absence of a European demos, it was argued, had logical implications for a democracy deficit. ${ }^{17}$ The impossibility of a European demos has been commented on with as much emphasis and frequency as the longing for a unifying 'glue' of sorts. The latter was expressed with some publicity by a joint initiative by Jacques Derrida and Jürgen Habermas in the French and German broadsheets, Le Monde and Frankfurter Allgemeine Zeitung, respectively. The initiative followed the 15 February 2003 demonstrations against the military intervention in Iraq by the United States and its allies. The two philosophers argued that a strong European civil opposition against the war would forge a new European identity. ${ }^{18}$ The action has been widely criticised, for example, Iris Young questioned its 'cosmopolitan' dimension, pointing out that it sought to establish identities which were not unlike those linked to modern nation-states, indeed. ${ }^{19}$

This demos discourse about the potential of civil republican citizenship notwithstanding, the concept appeared of little appeal to the wider academic community. ${ }^{20}$ Despite a booming European citizenship literature and endless policy initiatives and calls by the European organs, including the Treaty, to bring the

\footnotetext{
${ }^{15}$ For details of this argument, see Wiener 1998, Ch 4.

${ }^{16}$ See for many Habermas 1993, Grimm 1995, Grande 1996, Lehning 1998.

${ }^{17}$ Friese and Wagner 2002.

${ }^{18}$ This initiative was published in Le Monde and Frankfurter Allgemeine Zeitung in July 2003, respectively.

${ }^{19}$ See "Europa leerer Mittelpunkt: Widerstand gegen die US-Politik kann nur eine Dezentrierung der Demokratie leisten “ Iris M. Young, Frankfurter Rundschau 22 July 2003, p. 9.

${ }^{20}$ Note for example that the first political science textbook to include chapter on citizenship was not published until a decade after the legal stipulation of citizenship in Maastricht (Cini 2003) despite a booming citizenship literature.
} 
Union's institutions "closer to the citizens,"21 the masses remained distant. The distance appears logical from the position of citizenship “minimalists”, who argue that Union citizenship entails little substance compared with the institution of national citizenship. $^{22}$ Conversely however, a growing number of scholars have pointed out the "dynamic" and even "transformative” aspect of this citizenship and moved on to explore its constructive potential. ${ }^{23}$

\subsection{Findings}

The achievement of European citizenship depends on the yardstick it is measured by. If it is measured against the template of citizenship as a fundamental constitutional norm securing rights and identity for citizens as full members of nation-state communities, ${ }^{24}$ the result will invariably entail a notion of 'deficit.' Once it is measured against membership rights in other international organisations, such as, for example Mercosur or the North American Free Trade Agreement, the outcome will be one of 'surplus.' While this comparison is rather fruitless for an elaboration of citizenship substance, it does display the considerable influence of modernity on the majority of discussions about European citizenship. According to historical semantics, the relation between experience and expectation provides a key analytical tool of explanation and understanding behaviour. As I will elaborate in more detail below, it underlies much of the current academic literature and, indeed, policy-making on citizenship in Europe. $^{25}$

\footnotetext{
${ }^{21}$ See most recently Art 23 (6) of the Treaty of Nice which states "the Conference recognizes the need to improve and to monitor the democratic legitimacy and transparency of the Union and its institutions, in order to bring them closer to the citizens of the Member States.” [emphasis added, AW]

22 See O’Leary 1996, Oliveira 1995; Rosas 1995.

${ }^{23}$ See Meehan 1993; Shaw 1997; Wiener 1995, 1997, 1998; for the distinction between minimalists and dynamic approaches, see Meehan 1997.

${ }^{24}$ Rosenfeld 1994.

${ }^{25}$ See Esser (2002) on historical semantics, and Beck and Grande (2005, $33 \mathrm{ff}$ ) on methodological nationalism.
} 
The EU has always been conceived as a profoundly modern project including the major building blocks of modern nation-states such as centralised authority (held by the state), a limited territory (the Westphalian state), and a people (constitutionally ensconced by rights and identity as members of a political community). This perception involves assumptions about particular constitutional models and ways of interaction, most of which have been coined in a world of nation-states and positivist international law. For example, pending on the observer's view different ways of lawmaking e.g. creating meaning with a law that is hierarchical and free of the emotional aspects of politics following a Kelsenian approach or developing law in context following the Anglo-Saxon tradition, and different logics of political action e.g. interest-driven and actor-based, structural or intersubjective politics pursued by political actors such as parties, governments, lobby groups and so on ${ }^{26}$ have been applied to study the European citizenship policy. The preconception of modern stateness imposed on studies of European citizenship and European integration in general, involve unnecessary limitations towards what is constitutionally possible and desirable. $^{27}$

While most students of European integration would agree with this view, only some approaches meet the challenge of the radical deviation from assumptions of methodological nationalism which is required to assess the potential role and impact of beyond-the-state citizenship. After the formal stipulation of Union citizenship with the Maastricht Treaty different perspectives on Union citizenship came to dominate

\footnotetext{
${ }^{26}$ See Carty 1994 for the legal perspective and March and Olsen (1989) and Wiener (2003) for the distinction among logics of political action.

${ }^{27}$ As Beck has argued, for example, we need a new unit of analysis which does not succumb to the practice of 'methodological nationalism' (Beck 2005, 34). He has suggested to work with the term of a "cosmopolitan Europe" which is intended to create a third way which differs from an either Europe or the nation-state approach. (Beck and Grande 2005, 14)
} 
the academic discussion. The approach to citizenship as a practice has been increasingly drawn upon, albeit in different ways, by normative and socio-historical work. $^{28}$ It will be elaborated on in more detail below. The following summarises the socio-historical approach based on the concept of citizenship practice.

\section{European Citizenship Practice: A Socio-Historical Approach}

A socio-historical perspective is first and foremost interested in studying the relational dimension of citizenship. ${ }^{29}$ The focus on citizenship as a developing institution and its relation with the process of modern state-building allows us to identify the dynamic role of citizenship. This role brings the tension between the universal principle of equality among all citizens, on the one hand, and particularistic reality of the persisting inequality among individuals that reside within one community, on the other, to the fore. It allows us to examine citizenship practice as the politics and policy that deal with this tension and its impact on the organizational and philosophical task of accommodating diversity. Importantly, such perceptions of ideal citizenship are socially rooted. They evolve over time in relation to citizenship practice. If we are to understand the meaning of citizenship within a particular context - such as a polity or state - that is, if we are, in Marshall's words, looking for the source of the citizenship ideal, our empirical focus needs to involve social interaction. The following recalls the concept of “citizenship practice” based on constitutive and historical elements of citizenship. ${ }^{30}$

\footnotetext{
${ }^{28}$ See for example the work of Bellamy and Warleigh 2002, Shaw 1997, 1998; Pfister 2005, 2006, Jenson 1996, 2005; Kostakopoulou 2003, 2005; Wiener 1995; 1997; 1998; Wobbe and Otte 2001; Boes 2001.

29 See especially Tilly 1975; Somers 1994.

30 This concept was developed in discussions with Jane Jenson at Carleton University, it has been developed in Wiener $(1995 ; 1997,1998)$ and Jenson and Philips 1996, Jenson and P... 2002, Jenson 2005..
} 


\subsection{The Constitutive Elements of Citizenship}

According to political sociology citizenship is more than a universal norm. It also entails a practice related dimension. ${ }^{31}$ Citizenship is in one way or another considered as a crucial foundation for political communities. ${ }^{32}$ Its constitutive elements are the polity, the individual citizen and citizenship practice as the relation between individual and polity. Citizenship practice forges a specific historically contingent “citizenship ideal” in a given community and like all social constructs it is a “developing concept." 33 Indeed, “[T]he best approach is to view citizenship as a dynamic institution that changed with respect to time and place and with the developing sophistication of those who had to use and define it.”34

The role of citizenship in a constitutional context can be defined as follows. Citizenship practice sets the terms for the institutionalized relation between the citizens and the political community. The institutions which regulate the practice of citizenship include principles of justice, the adherence to formal political and legal procedures, as well as a set of norms and values. All contribute to establish the procedures of political participation and day-to-day practices of citizen participation within $a$ particular politically defined community. Citizenship entails the entitlement to belong to that community. The community, in turn, has the right and the obligation to represent community interests as a sovereign vis-à-vis other communities and vis-àvis the citizens as well. The relationship then links two types of entities, the individual citizen on one side, and the representative of a sovereign community

\footnotetext{
${ }^{31}$ See even political theorists' move towards involving the citizenship as a practice for example of "reflexive acts of democratic iteration by the people who critically examines and alters its own practices of exclusion.” (Benhabib 2004: 21)

${ }^{32}$ See Tilly 1975; Bendix 1968; Marshall 1950; Jenson 1992; Somers 1994; Boes 2001; Brubaker 1989.

${ }^{33}$ Marshall 1950, 28

${ }^{34}$ Riesenberg 1992, 141.
} 
(Queen/estate/nation-state) on the other. This relationship represents the basic pattern of citizenship. To study citizenship, three elements need to be considered then. They are the individual, the political community, and the relation between both. They are called the three constitutive elements of citizenship.

FIGURE 1: The Constitutive Elements of Citizenship

\section{Individual}

\section{令 $\Leftrightarrow$ Citizenship Practice}

\section{Political Community}

Source: Wiener 1998, 22

This relationship has, for a long time, been intrinsically linked with state-building. Indeed, it is possible to state that citizenship, or the discourse about it, defines the "borders of order” (Kratochwil 1994). It set the rules of who belongs to a community and who does not. While there are exceptions to the rule, such as dual-citizenship for a selected few citizens, by and large, citizenship is an exclusive concept. ${ }^{35}$ It is about entitlements and duties for a chosen few with a view to binding and grounding them within one particular community. As such, it forms the core of a politically organized modern community. However, citizenship is not restricted to top-down institutionbuilding. Historical studies have demonstrated that political struggles over the expansion of citizenship rights have, in fact, contributed to forge the very communities. Bottom-up mobilization is hence another important factor in the emergence of citizenship. ${ }^{36}$ In sum, talking about citizenship invariably involves a

\footnotetext{
${ }^{35}$ See Koslowski 1998, Joppke 1998 and Benhabib 2004, respectively.

${ }^{36}$ See Tilly 1975, Bendix 1969, Jenson 1991, Turner 1990.
} 
notion of stateness. $^{37}$ Since Union citizenship has been introduced to the constitutional framework of a non-state, it challenges such assumptions. As Deirdre Curtin points out "the unique sui generis nature of the Community, its true worldhistorical significance [is constituted by its character] as a cohesive legal unit which confers rights on individuals.” ${ }^{38}$ Subsequently, apart from being a new supranational institution, as a new transnational practice it also calls the role of national citizenship as one key institution in the history of modern state-building into question.

\subsection{The Historical Elements of Citizenship}

Modern citizenship is characterized along two functional dimensions which where central to the construction of borders, both between states and within societies. The first dimension is about rights, including the civil right to free movement, the political right to vote, and the social right to access to education and the distribution of welfare. The second dimension is about identity that is, belonging to a particular national community.

\footnotetext{
${ }^{37}$ Barbalet 1988, Brubaker 1989, Turner 1990, Hobe 1993.

${ }^{38}$ See Curtin 1993, 67, c.f. Shaw 2001, 381.
} 
Figure 2: The Modern Geography of Citizenship

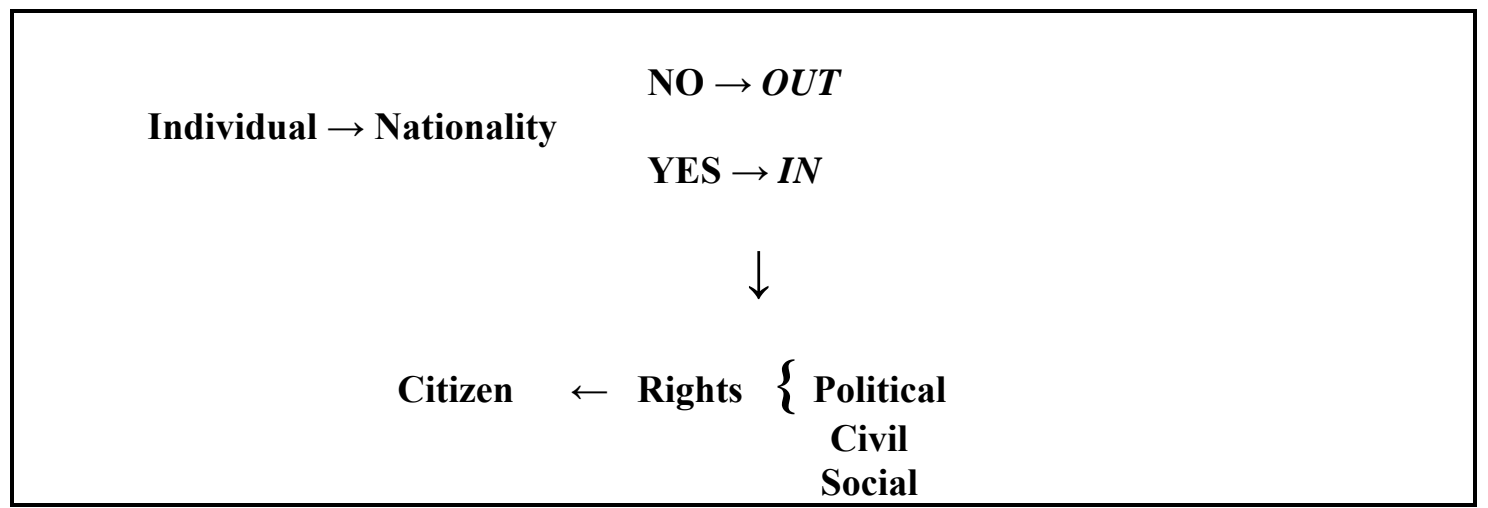

Source: Wiener 1997,532

Both dimensions were linked to the project of forging statehood and stabilizing territorial borders of states. Within the framework of political philosophy these dimensions were represented by the liberal vs. the republican approaches to citizenship. Roughly, both approaches differ according to the liberal assumption that citizenship is about individual rights. These rights are universally derived and locally established. According to the republican approach citizenship is about the process of governing and being governed. This practice ultimately contributes to the establishment of a particular identity which, in turn, makes communities distinguishable from each other.

In turn, historical studies of citizenship reveal the key role of three historical elements of citizenship. The first element is rights which establish how the individual is legally related to the polity. Access as the second element of citizenship is about the conditions for practicing the relationship between citizen and community. This element is best understood as access to political participation. Conditions of access are set by regulative policies including social policy, market policy and visa policy, for example. They are crucial determinants as to whether or not individuals are fit to participate politically. Access therefore hinges on socio-cultural, economic and 
political mechanisms of inclusion and exclusion. That is, while rights may have been stipulated, access may be denied because the means to use citizenship rights, such as proper education, communication, transportation may not have been sufficiently established. The third historical element encompasses two modes of belonging to a community. One is identity-based, the other hinges upon legal linkages to an entity which are currently based on either the law of soil (ius solis) or blood (ius sanguinis) respectively, or, as in the EU, on nationality of one of the member states. Crucially, belonging is based on both the legal entitlement to a national passport (Hailbronner 1997) and the cultural experience of belonging to a particular place (Kaplan 1993). Every person residing within a particular area has potentially the opportunity to participate in creating collective identities which may evolve through participation at the work place, in cultural matters, or other spaces. Residence is therefore a key aspect for participation. This socio-cultural importance notwithstanding, it is the legal status -nationality 'yes’ or 'no' (see Figure 2) - which stipulates whether or not an individual is considered as a citizen with full membership of a community. ${ }^{39}$

While full membership, in principle asserts to the full participation in all citizens' rights and duties within a community, in reality, this status has always remained exclusive. For example, women have been excluded from suffrage and are still excluded from military service in many countries. This dimension of belonging is therefore also about borders as citizens derive certain rights and opportunities of access based on their belonging to a bounded sphere. More specifically this feeling of belonging depends on a previous process of “drawing boundaries” around the terrains

\footnotetext{
${ }^{39}$ This sociological approach to citizenship as entailing three dimensions has also found its way into political theorist’s work. In Benhabib words “[T]he practice and institution of citizenship can be disaggregated into three components: collective identity, privileges of political membership, and social rights and claims.” (Benhabib 2004, 145)
} 
which are designed for those citizens who belong. As Kratochwil notes, "[i]t is perhaps best to conceive of citizenship as a space within a discourse on politics that institutionalized identities and differences by drawing boundaries, both in terms of membership and in terms of the actual political practices that are connected with this membership. An explication of the concept, therefore, is not governed by the atemporal criteria of adequacy or correspondence. It necessarily becomes historical, requiring an examination of the genealogy of the concept and its temporary reconciliations.” (Kratochwil 1994, 486) To understand the particularistic meaning of citizenship (how are universal citizenship rights realized within a particular community at a particular point in time?) then, the interplay between citizenship as a practice and as a theory facilitates key information. From this perspective it is possible to find out, how citizenship is continuously contested and reconstructed over time. It offers a methodology for the examination of the historical variability of citizenship based on the three historical elements of rights, access and belonging.

FIGURE 3: The Historical Elements of Citizenship

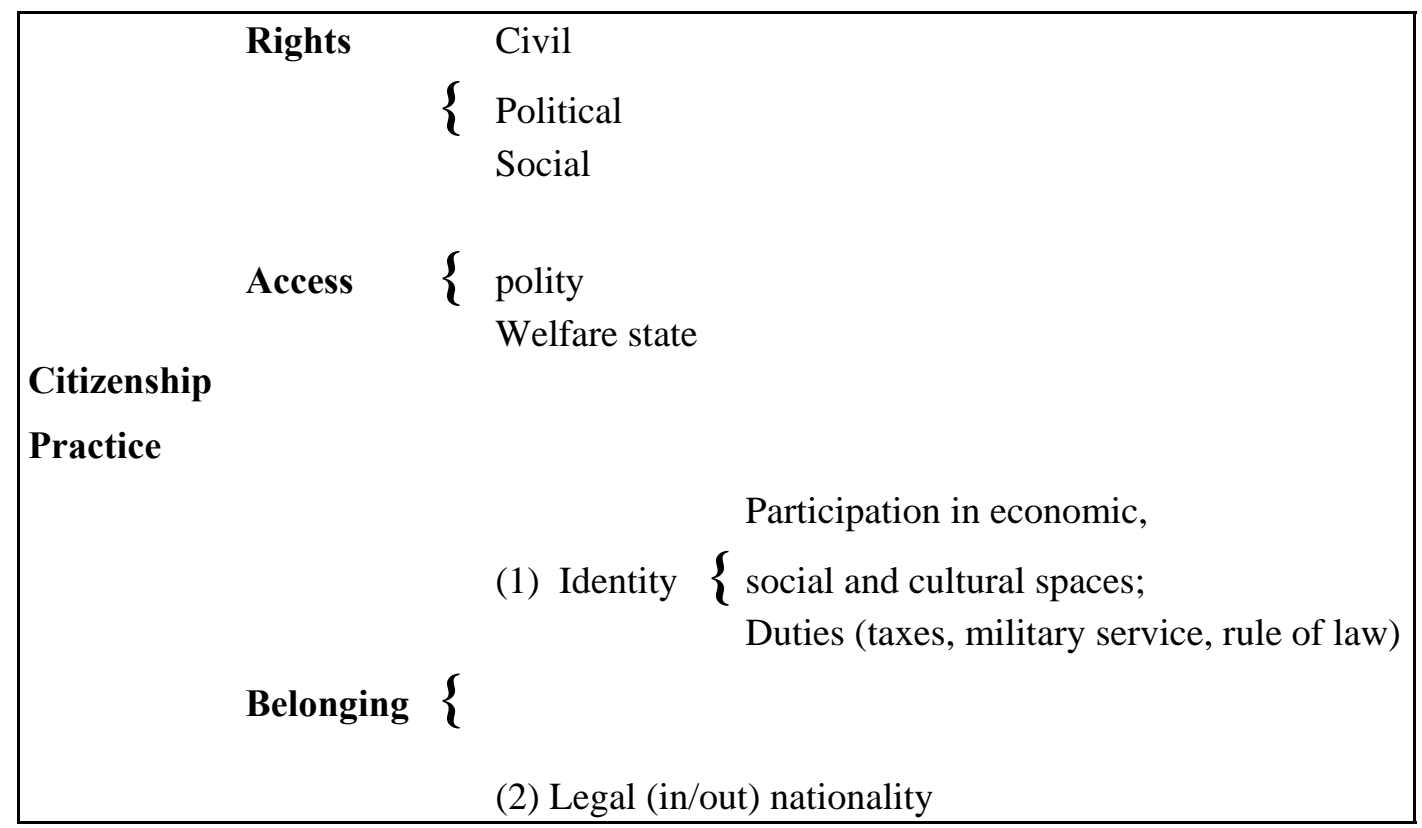

Source: Wiener 1997, 536 
To summarize, two insights about the role of citizenship in the formation of political communities can be gleaned from history. First, the terms of citizenship are the product of an ongoing process, involving debates about the terms of citizenship and struggles for access to participation. This process has contributed to create shared values and norms among the participants, forging a feeling of belonging to a specific group or community. Secondly, the three key types of modern citizenship rights have been shaped and established in distinguishable processes over two centuries. Marshall's study importantly points to the - often overlooked - fact that citizenship rights are not necessarily all introduced at the same time, nor does their institutionalization mean that all citizens will benefit from them in an equal and fair way. Indeed, modern citizenship rights were bundled only relatively recently when they were crystallized in modern welfare states in the second half of the twentieth century (Soysal 1996). It follows that citizenship consists of different elements which might be bundled into one set at some times and stay fragmented at different levels and with different implications for the involved citizens at other times. From the longterm perspective, they were fragmented for about 200 years, then they were bundled in the post-war decades and now, since the 1980s, their fragmentation has begun yet again. Social scientists might therefore legitimately raise the question of whether the current period of fragmentation will lead towards another stage of bundled citizenship. And if so, what if not the nation-state will be the entity or the entities of reference for that citizenship?

The perception of citizenship as a developing institution facilitates a helpful access point for the changing conditions of citizenship in the European Union. If, as Marshall suggests, the ideal is formed in societal contexts, it follows that a diffusion of these 
contexts based on blurred geographical boundaries and pooled sovereignties poses a challenge to nationally constructed citizenship ideals. In turn, the lack of what we might call an updated citizenship ideal reflecting the beyond-the-state context of citizenship practice, poses a threat to the organizing capacity of citizenship. The perception of this threat is well reflected, for example, in the debate over a “democracy deficit” in the EU which is based on the lack of a shared identity (ethnos) and the absence of a European political community (demos) as a challenge to the principle of democratic majoritarian rule. ${ }^{40}$ Putting citizenship practice into place by way of exploring and adding new types of citizenship practice to the familiar practices of modern times, thus allows us to identify general changes in strategy and outcome (institutionalised terms) of citizenship practice over time. To that end, it is helpful to examine objectives (goal) and perspectives (place) of citizenship practice as the politics and policymaking towards the establishment of citizenship rights proceeds.

\section{Two Accounts of Citizenship Practice: Law and Politics}

As a developing concept, European citizenship has now been part of the integration process for three decades. However, awareness of this citizenship has had a much shorter life-span. The big debates were only sparked relatively recently by the constitutionalisation of citizenship with the Maastricht Treaty. Up to that date, European citizenship had developed - since the late 1960s - largely hidden from the academic and public view. ${ }^{41}$ In the early 1990s, Beverly Springer described the situation thus, "[n]o commissioner and no DG have, as a primary responsibility, the development of citizenship policy. Different aspects of the policy are scattered among

\footnotetext{
${ }^{40}$ See Scharpf 1995, Grande 1996, Grimm 1995.

${ }^{41}$ A few notable exceptions notwithstanding, however, as the work of Meehan (1993) Evans (1985), Magiera (1991) and Closa (1992) shows.
} 
the responsibilities of several commissioners and their DGs." ${ }^{42}$ Citizenship policy resembled more a multidimensional "jigsaw” puzzle than a traditional policy. ${ }^{43}$

As the following sections will elaborate more in detail, the trajectory of this first supranational citizenship has wider implications for institutional and conceptual change that apply beyond Europe. The key to understanding of just how much of an innovation this citizenship presents, notwithstanding its substantive and legal shortcomings, lies in the fact that a supranational citizenship was put on a par with national citizenship. Overnight, so to speak, citizens of the European Union who were nationals of an EU member state acquired a new citizenship in addition to their national citizenship. At the same time, residents of the EU who did not hold a member state passport such as, for example, many Turkish residents in Germany, or Moroccan residents in France, became third country nationals.

The literature displays not one but two stories of the emergence of European citizenship, each following a distinctive trajectory. The first story recalls citizenship as evolving through the process of integration through law that has been pushed by the ECJ's case law. The second is based on a series of discussions and deliberations among policymakers and politicians in the context of the EC and later, the EU. Both trajectories have developed according to different logics and, curiously, they have rarely been compared. As socio-historical research has convincingly demonstrated, in

\footnotetext{
${ }^{42}$ See Springer 1994, 144; the abbreviation 'DG' means European Commission Directorate General.

${ }^{43}$ As one commission official noted, "[i]nformation on Union citizenship is widely scattered within the Commission." Interview with Kerstin Jorna at DG XV, Directorate A 3 of the European Commission, Brussels 13 June 1994 (on file with author). Note that for researchers on European citizenship in the early 1990s, this meant establishing inter-institutional links among the supranational institutions, as well as between the supranational and the domestic institutions. In addition, in the absence of today's elaborate world-wide web services, policy documents had to be traced and physically dug out from historical archives and multiple offices scattered across Brussels.
} 
order to fully grasp the range of political and conceptual implications of European citizenship, it is essential to place the emergence of European citizenship within a larger time frame. Therefore, the following sections present a moving picture that is able to reach back long before citizenship appeared in the Maastricht Treaty, rather than a snapshot, on one selected moment in time.

\subsection{Law}

A legal perspective on Union citizenship focuses on the gradual enhancing of citizens' rights from 'market citizenship' towards 'political citizenship', through legal integration. In other words, cases brought to the ECJ by EU citizens are the main empirical material for lawyers. Legal scholars are also interested in how citizenship rights and citizens, as the subjects of law, figure within the emerging trans- and supranational legal order. For example, they are interested in how legal practice and new institutions impact on the strict distinction between national or constitutional law on the one hand, and international law, on the other; and what the implications for the practice of national law within each member state of the EU are. International law, European law and the 25 national legal contexts of the current member states, all have an impact on perceptions of the role and meaning of Union Citizenship. For example, each member state has to adapt its legal procedures and legislation in line with new European directives. Is it, for example, legitimate to speak of a particular European citizenship law in the making? The direct link between citizens and the EU seems to suggest such an interpretation. There are doubts, however, as to whether or not the substance of Union citizenship is comparable to 'nationality' or 'national citizenship.' Are there possibilities of further developing this institution legally?; what are the likely legal practices involved?; which rules guide this process; and which institution has the competence to define the rules? 
To answer these questions, lawyers recall the evolution of European citizenship, which began in the 1950s with the introduction of "market citizenship." ${ }^{44}$ Lawyers point to the fact that it was in the late 1950s that European integration began to push beyond the narrow confines of a freedom of movement principle that was originally related exclusively to the market. They show that what were originally conceived of as the rights of market citizens were gradually expanded. As Kostakopoulou states, for example, "workers are not seen as mere factors of economic production, but as human beings." 45 Subsequent rulings on labour and social rights also followed this line. For example, as early as 1958, two Regulations on the social security of migrant workers were passed in the Council, one of which characterized the right to freedom of movement as a fundamental right of workers to improve their standard of living, which must be exercised in freedom and dignity.

Overall, it is important to understand that the process of negative integration, i.e. the removal of obstacles to free trade across internal borders within the Community, guided the first steps towards the construction of a European citizenship. It set the framework for positive integration which focused on more explicit policy steps towards creating European citizenship that were developed from the 1970s onwards. The market-based logic suggests that the Treaties already entailed an 'incipient form of European citizenship' in 1958, if only for certain groups, such as workers, professionals, service providers and their families. ${ }^{46}$ The four freedoms, among them the freedom of movement, are not generally seen as contributing in any strict legal

\footnotetext{
${ }^{44}$ See Kadelbach 2002, 2; Marias 1994, 1; Everson 1995; Kostakopoulou 2001.

${ }^{45}$ Kostakopoulou 2001, 40.

${ }^{46}$ See Plender 1978; Kostakopoulou 2001, 41.
} 
sense to Union Citizenship. Yet, "it is out of the field of free movement that the concept of citizenship in the EU context largely emerged.”47

In sum, the case law of the ECJ laid the early foundation of a 'rights-based' approach to freedom of movement. That 'market citizens' were moving across borders and residing in member states other than that of their own nationality raised all sorts of practical issues, including social insurance, fundamental rights, non-discrimination on the grounds of nationality, and so forth. Two larger issues had an impact on the evolving concept of European citizenship, ${ }^{48}$ namely the protection of social rights, and the question of political inequality. The first was largely dealt with by the case law of the ECJ; the second was taken up by political actors such as the EU institutions and interest groups. This section recalls the first issue and then turns to the second issue in the following section.

A notable case was for example Martinez Sala v. Freistaat Bayern. ${ }^{49}$ The Martinez Sala case is important as it offers an account of the link between legal practice and the evolving concept of Union citizenship. In this case an unemployed Spanish citizen had moved as a market citizen to Germany and had been living there since 1964 . However, while she had not had a residence permit since 1984, she put in a request of family (child-raising) allowance in 1993. Her application was rejected on the ground that she did not have German nationality, a residence entitlement, or a residence permit. The key question put to the Court was whether, as an unemployed person, Ms. Martinez Sala had the right to freedom of movement and residence according to Art

\footnotetext{
${ }^{47}$ Shaw 2000, 377.

${ }^{48}$ O’Leary 1996.

${ }^{49}$ See 1998. 'María Matínez SALA vs. Freistaat Bayern, NL 98/3/10 Rs. C-85/96 http://www.sbg.ac.at/oim/docs/98_3/98_3_10.htm
} 
18 EC and whether she could put her case forward as a Union citizen. Martinez Sala finally won her case. ${ }^{50}$ The legal reasoning in the judgment makes explicit reference to Martinez Sala’s right to non-discrimination on the grounds of nationality (as in Art 12, EC Treaty), it does, however not make the case on the basis of Union citizenship (Arts 17-22 EC Treaty).

Other important cases that demonstrate the fragmented quality of citizens' rights in the EU, that is, cases that involve demands that are not necessarily or exclusively based on the Citizenship clauses in the Treaty but which are situated elsewhere in the Treaties, include the application of the right to equal pay for men and women (Art 141, EC Treaty), a right which emanated from French labour law. This stipulates that “[E]ach member state shall [...] ensure and subsequently maintain the application of the principle that men and women should receive equal pay for equal work.” The expanded Equal Treatment Directive ${ }^{51}$ included access to employment, vocational training and promotion, and working conditions. A good example of the application of this European right was the Tanja Kreil case. In this case, a German woman complained about her exclusion from the German military exclusively on the grounds of sex. ${ }^{52}$ Kreil sued the German armed forces, claiming that the rejection of her application on grounds based solely on her sex was contrary to European law. She

\footnotetext{
${ }^{50}$ The ECJ ruled that "for the purposes of recognition of the right of residence, a residence permit could only have declaratory and probative force. Consequently for a member state to require a national of another member state who wished to receive a benefit such as the allowance at issue in the main proceedings to produce a document which was constitutive of the right to the benefit and which was issued by its own authorities, when its own nationals were not required to produce any such document, amounted to unequal treatment which, in the absence of any justification, constituted discrimination prohibited by art 6 of the EC Treaty. It followed that Community law precluded a member state from requiring nationals of other member states authorized to reside in its territory to produce a formal residence permit issued by the national authorities in order to receive a child-raising allowance, when the member state's own nationals were only required to be permanently or ordinarily resident in that member state" (Court of Justice 1998).

${ }^{51}$ 76/207/EEC.

${ }^{52}$ Case C-285/98 Tanja Kreil/Bundesrepublik.
} 
stated that Art 12a of the Basic Law of the Federal Republic of Germany 'constitutes direct discrimination. ${ }^{53}$ The ECJ ruled in her favour (Wobbe 2003). A third case of great influence for the diffusion of citizenship rights based on the principle of nondiscrimination is Grzelczyk. In this case it was ruled that as a French national studying in Belgium Mr Grzelczyk was eligible for a minimum subsistence allowance paid by the Belgian state, provided that he satisfy the requirements outlined in Art 1 of Directive 93/96 (self-sufficiency and possession of sickness insurance). ${ }^{54}$

To summarize, case law offers important information about how Union citizenship affects the lives of citizens, and the development of legal and political institutions and procedures, both in the member states and at EU level. The issue of political inequality was taken up by political actors, triggering deeper questions about equality and citizenship, as the following section will demonstrate. The introduction of citizenship as an institution in the EC Treaty has thus had a number of implications for institutional adaptation in the member states as well as in the candidate countries. For example, member states are responsible for the adaptation of electoral laws and procedures, and the court's case law will continue to play a key role in guarding the principles and rights entrenched in the Treaties. Here it will be particularly interesting to see whether citizens will increasingly turn to the ECJ with their complaints. In addition, it will be interesting to see how the debates about the citizens' right to "the right to move freely and to reside on the territory of the Member States” (Art 18 TEC)

\footnotetext{
${ }^{53}$ C-285/98, Judgement, 11 January 2000, No. 11.

${ }^{54}$ See Kostakopoulou 2005, 252 for further details of the case; for the judgement on Grzelczyk vs. Centre public d'aide sociale d'Ottignies-Louvain-la-Neuve see http://www.europa.eu.int/jurisp/cgibin/form.pl?lang=en\&Submit=Submit\&alldocs=alldocs\&docj=docj\&docop=docop\&docor=docor\&doc jo $=$ docjo \&numaff $=\&$ datefs $=\&$ datefe $=$ \&nomusuel $=$ Grzelczyk $\&$ domaine $=\&$ mots $=\&$ resmax $=100$ <assessed 28 February 2006>
} 
will pick up. After all, according to the transition rules of the enlargement agreements, this fundamental freedom of all Union citizens remains restricted for citizens of some of the ten new member states that joined the EU in 2004. While access is restricted for a limited period, and the conditions where negotiated among the EU and the then candidate countries as partners in the accession process, it nonetheless does create a situation of inequality between old and new member state citizens. Here, citizens may experience a growing feeling of unequal treatment under the EC Treaty that has all the potential to spark conflict in the union.

\subsection{Politics}

From the early 1970s policy making on Union citizenship unfolded on the basis of two policy packages, “special rights” for Community citizens and a "passport union.” These policy objectives were adopted in the Final Communiqué of the 1974 Paris Summit. Both touch on crucial aspects of modern citizenship, such as borders and how to cross them (passport union), and the citizens' right to vote and stand for elections (special rights). These have been central to the debates about citizenship, European identity, and political union, which have been evolving since the early 1970s and received a strong push after the Maastricht IGCs. This section demonstrates that the step-by-step development and application of these two policy packages provides an insight into how citizenship was eventually included in the Maastricht Treaty 20 years later. It also suggests that over time Union Citizenship acquired a specific meaning, forging a European citizenship ideal which was both fragmented and transnational in the process. It is important to note, however, that this outcome had not been envisaged by those who identified the goals and policy objectives of citizenship practice in the early 1970s. The story of European citizenship practice thus reveals a case of institution building which created unintended 
consequences. $^{55}$

3.2.1 Citizenship Policy from the 1970s to the 1990s

In the early 1970s EC politicians and practitioners expressed their desire to enhance the European presence on the global stage. To that end, it was suggested that the Community should work towards a stronger European identity. The adoption of the 1976 Council Decision implementing direct universal suffrage; the first European elections in 1979; and the adoption of a Council Resolution on the creation of a single European passport in 1981 were crucial first steps. Besides these institutional changes the citizenship discourse had also been expanded to incorporate the idea of 'Europeanness', introduced in a document on "European Identity” in $1973 .{ }^{56}$ Thus, from early on, citizenship practice was linked to the project of building a political Union in Europe based on the project of creating a stronger sense of identity in the then - European Community.

In the 1980s, the bold political 'kick-off' for citizenship practice that had occurred during the previous decade was slowed down. Economic uncertainty, widespread concerns over ungovernability in the member states, an increasing sense of Eurosclerosis, unsolved budgetary problems and a general feeling of pessimism, all led to a stronger focus on market-making or economic integration. Instead of the aspirations of positive integration (building European Union, creating citizenship), negative integration (removing obstacles within the free market) was prioritized, with the freedom of movement of workers as a key condition for economic flexibility. In other words, it was not access to the polity (the political right to vote) but access to

\footnotetext{
${ }^{55}$ See North 1990; Pierson 1995; Wiener 2001.

${ }^{56}$ Europe Documents, No. 779
} 
participation in a socio-economic sense that became the major concern of citizenship practice during this period. The then President of the European Commission, Jacques Delors’ call for a “Europe without Frontiers by 1992” guided this effort. Thus, aside from abolishing internal Community borders, the related Single Market Programme included new strategies for the creation of a European identity. ${ }^{57}$ This involved the extension of access to the market on a group-by-group basis. For example, a new mobility policy targeted groups such as young people, teachers and students. Among these programmes were the ERASMUS programme ${ }^{58}$ and the Young Workers' Exchange Scheme (YES). The European Parliament stressed the importance of programmes, such as these in the building an ever closer union, when it observed that “[c]ooperation among the Member States of the Community in the field of education and culture is inherent to the process of the construction of Europe, and reflects the spirit of the Treaties, since there is no doubt that it promotes closer relations between peoples." 59

Three new directives established the right of residence for workers and their families as well as for students. Two types of special rights were also negotiated. First, a series of social rights, including health care, the right to establishment, old age pension, the recognition of diplomas, were defined with the Social Charter. These rights were the economic and social conditions, which would prevent social dumping. Importantly,

\footnotetext{
${ }^{57}$ As a Commission programme explained, “[R]ecognition as a 'Community centre of excellence' for establishments giving additional training or conducting very advanced research in specialized areas would help towards the increased mobility of students and research scientists within the Community. The European Council should express its support for these types of activity, which will promote the European identity in the eyes of the economic and social decision-makers of the future of the Community." (Commission 1985)

${ }^{58}$ The acronym stems from the programme's name European Community Action Scheme for the Mobility of University Students.

${ }^{59}$ See European Parliament 1996; Laffan 1996.
} 
for the development of European citizenship, crossing borders to work in another member state meant that so-called foreigners (in this case, Community citizens working in a member state of which they were not nationals) and nationals shared day-to-day economic life, yet remained divided when it came to their political rights. Secondly, this situation evoked awareness of a democratic deficit in the European Community. For example, the Commission identified that the impact of economic integration at times implied a loss of political status. Citizens who moved across internal community borders faced a loss of access to political participation. To overcome this dilemma the Commission proposed the establishment of voting rights for 'foreigners' in municipal elections. This proposal for a Council directive was drafted with a view to closing of the growing gap in political status between foreigners and nationals. Bringing the political right to vote back onto the policy agenda was largely facilitated by the possibility of 'dusting off' a previously created informal resource of the acquis, namely equal political rights for European citizens.

Demands for greater access to participation, both in political and socio-economic terms, were renewed in the 1990s. With the Maastricht Treaty and the end of the Cold War, the political project of Union-building was back on the political agenda. Critical perspectives on European identity as part of citizenship practice were brought to the fore. "[F]rom the outset, the Community had considered itself as synonymous with 'Europe.' With the Cold War over, [the question became] could the Community foster a sense of pan-European solidarity and genuinely pan-European integration?”60 These questions challenged the discourse on European identity which had been so crucial for the emergence of citizenship practice in the early 1970s. At that time, European

\footnotetext{
${ }^{60}$ Dinan 1994, 158.
} 
identity had meant West Europeans only. Now, the end of the Cold war cast a new light on the term, emphasizing that some Europeans had been left out all along. Also significant for citizenship practice was the instability of the Paris-Bonn axis, which had proved a solid foundation for European integration thus far, as German Chancellor Kohl pushed for fast German unification while French President Mitterrand was "torn between an instinctive antipathy toward German unification [...] and an equally instinctive affinity for European integration.”61 One way of addressing this tension was to forge a link between German unification and European integration. This solution contributed to a renewed emphasis on political integration. It created a window of opportunity for those actors interested in establishing a European citizenship. In particular, a number of Spanish proposals pushed the process of citizenship practice during the period that immediately preceded the Maastricht IGCs.

Until that point, two types of policy resources had been mobilized by citizenship practice since the early 1970s. First, citizenship was to grant rights that were specific to the European Community as a polity and as a social space. Second, the visible sign of Union Citizenship, when travelling outside the Community was to be the uniform passport. Both of these resources were formalized at Maastricht in Art 8 TEC. To summarize, while the end of the cold war in 1989 and the renewed emphasis on political integration in Europe had opened a window of opportunity to establish political citizenship rights, the larger history of citizenship practice since the 1970s reveals that the meaning of Union citizenship is not derived from the sum of the member states' national citizenship rights and practices; nor can its substance be deduced from the concept of modern citizenship. Instead, citizenship of the Union

\footnotetext{
${ }^{61}$ Dinan 1994, 163
} 
was constructed anew, albeit drawing on past experiences with citizenship, with its own characteristic features. The 1990s saw the institutionalization of political and legal citizenship rights. Although the historical element of belonging had been addressed in the previous two periods, now, the focus was set on establishing legal ties between citizens and the EU. These were not only important for redefining the link between citizens and the Community, but also raised questions about the political content of nationality. This third period of the developing practice of European citizenship also meant a shift away from 'modern’ citizenship by making nationality of an EU member state the precondition for Union citizenship.

\subsubsection{Citizenship Practice Post-Maastricht}

The constitutionalisation of 'thin' citizenship meant in practice an institutionalized fragmentation of citizenship. In other words, some rights of European citizens were identified by the citizenship articles (17-22, TEC), whereas others were outlined elsewhere in the Treaties. ${ }^{62}$ A fourth period of citizenship practice demonstrated a growing mobilization around and a rising confusion over the consequences of this fragmentation. The EP organized hearings in Brussels during which nongovernmental organizations (NGOs) could express their demands to the IGC. While NGOs were not formally entitled to participate in the IGC process, and had no formal channels for participation, these hearings nevertheless offered space for discussion. Post-Maastricht a new debate unfolded over the gap between politically included and

\footnotetext{
${ }^{62}$ As the Commission states in its Third Report on Union Citizenship "[u]nder the terms of Art 17(2) of the EC Treaty, citizens of the Union are to enjoy the rights conferred by this treaty and are to be subject of the duties imposed thereby. The rights that feature in Part Two of the Treaty, under the heading Citizenship of the Union, thus form the core of the rights conferred by citizenship, but are not an exhaustive list. The EC Treaty confers on citizens of the Union other rights which appear elsewhere in the Treaties, such as protection from all forms of discrimination on grounds of nationality (Art 12). It is therefore legitimate for this Third Report on Citizenship of the Union to go beyond the specific rights featuring in the second part of the EC Treaty and to examine subjects that have an obvious connection with citizenship of the Union, such as the fight against all forms of discrimination and, more generally, the protection of fundamental rights in the Union.” (Commission 2001, 6)
} 
excluded residents, that is, between citizens who had legal ties with the Union, and so-called third-country nationals, individuals who had no legal ties but are likely to have developed feelings of belonging nonetheless (see Figure 3). This debate was pushed by interest groups and by the European Parliament.

In the debate over third-country nationals it is important to recall that once the Berlin Wall came down, the European Community had to face a new challenge in the area of border politics; namely visa and asylum policy, which involves the question of eastwest migration. ${ }^{63}$ One idea which was mooted as a way of solving this potential political problem was the establishment of "place-oriented citizenship." ${ }^{44}$ This entered the European Parliament debate ${ }^{65}$ and has led to pressure from social movements to change citizenship legislation in the Treaty. For example, instead of granting citizenship of the Union to "[E]very person holding the nationality of a Member State” (Art 8 (1)), as was the case post-Maastricht, a number of advocacy groups such as, for example, the European Citizen Action Service (ECAS) or the ARNE Group requested citizenship for "[e]very person holding the nationality of a Member State and every person residing within the territory of the European Union"66. However, the Amsterdam Treaty did not reflect these demands. On the contrary, the nationality component of citizenship was reinforced, within revised Arts 6(3) TEU and 17 TEC which state that the national identities of the member states must be respected. The potential flexibility of the citizenship article (8e EC Treaty) was thus left unexplored. Yet while the formal institutional aspects of Union Citizenship thus largely remained as they were, the informal aspects of European

\footnotetext{
${ }^{63}$ Uçarer 2003.

${ }^{64}$ Wiener 1996.

${ }^{65}$ See for example the Outrive and Imbeni Reports (c.f. Wiener 1998)

${ }^{66}$ Antiracist Network for Equality in Europe 1995 c.f. Wiener 1998
} 
citizenship witnessed further reform in the post-Amsterdam period, so that the European institutions began to work more with national representations, national parliaments and NGOs on citizens demands, in order to react to growing disaffection with the European integration process. 'Citizens First' and its successor programme 'Dialogues with Citizens and Business', campaigns initiated by the EP and introduced to the member states by the Commission to bring Europe closer to its citizens, are examples of this change of emphasis.

\section{Conclusion}

From Aristotle to more recent observations about how negotiating citizens' rights have contributed to building the modern state, the most significant aspect of citizenship has been its definition vis-à-vis forms of the state. Its political function seemed clear, namely, “in Western, liberal democracies public authority requires legitimation through one principal source: The citizens of the polity."67 Much of the literature suggests that the explanatory potential of citizenship lies precisely in its contribution to forging the central authority in modern communities, i.e. the state. Europeanization and globalization present two significant challenges to modern state-citizenship relation. Thus, it is particularly visible in the European context that "the processes which created and sustained sovereign territorial states in this region are being reversed.”68 While the - discursively constructed - merger of demos (Gesellschaft) and ethnos (Gemeinschaft) contributed to create the powerful belief in national unity based on "imagined communities"69 as the basis of political organization in a civilised world, the current process detangles that process.

\footnotetext{
${ }^{67}$ Weiler 1996, 6

${ }^{68}$ Linklater 1996, 77.

${ }^{69}$ Anderson 1983.
} 
The elaboration of Marshall's socio-historical concept of citizenship as entailing a triad of rights allows for an encompassing definition of citizenship as the set of institutions which determine and reflect the rights, access and belonging of individuals to a polity. Reconstructing the emergence of European citizenship based on this approach finds a dispersion of ethnos and demos, the fragmentation of identities, and the diffusion of state sovereignty. These findings raise critical questions about the stability of the modern image of identity and unity. After all, once individuals began to enjoy different types of rights in a new world that reflects flexibility and mobility, it has become increasingly difficult to define citizenship practice based on nationality. ${ }^{70}$ The concept of citizenship practice offers a suitable empirical vantage point for studies seeking to establish not only the interests and motivations that lay behind the movement towards legal citizenship. They also help reveal the "structure of meaning-in-use"71 of citizenship in particular contexts. If we want to analyse the substantive meaning of citizenship as a norm in any particular society, including the European society, a focus on the historical elements of citizenship is particularly helpful.

Despite formal institutional changes in the treaty framework and in the constitutions of the member states, Union citizenship remains contested. Not only do academics differ in their assessment on what this citizenship has in store as it stands now, let alone with regard to its future potential, local councils, regional governments and

\footnotetext{
${ }^{70}$ Meehan captured this fragmented aspect of European citizenship noting that it is "neither national nor cosmopolitan but that is multiple in the sense that the identities, rights and obligations associated [...] with citizenship, are expressed through an increasingly complex configuration of common Community institutions, states, national and transnational voluntary associations, regions and alliances of regions.” (Meehan 1993, 1).

${ }^{71}$ Saco and Weldes 1996, Milliken 1999 on the concept, and Wiener 2006, in preparation for the structure of meaning-in-use with relation to the fundamental norm of citizenship in Europe.
} 
member state civil servants are faced with the implementation of EU law. The highly fragmented and contested nature of the local election procedures is but one example for the contested nature of citizenship legislation with direct impact on the daily life of European citizens. ${ }^{72}$ The widely differing expectations, demands and assessments have been conducive towards debate. Conflicting views on European citizenship contribute not only to refine the meaning and potential of European citizenship, they also bring the more general question of civilized and democratic organization in an increasingly globalised world to the fore. In this process the contestedness of European citizenship is a key asset.

As a new supranational institution and transnational practice, European citizenship has repercussions on the relation between citizens and 'their' community along three core dimensions. They include, first, the identity of citizens (who does belong where and why?), second, the type and range of rights citizens can evoke (which rights can be evoked with which institution on which level?), and thirdly, the channels of access to participation in the wider political and social community of European citizens (who can participate on what grounds and where, i.e. socially, economically, culturally, politically?). Three dimensions have wider implications for the type of community the EU might become, elaborating on them bears some key answers to the social construction of the EU's political substance rather than forcing premature debates about "political finality"73 based on unsuccessful referenda. Understanding the whole story of European citizenship practice, i.e. the policy and politics which contribute to set the institutional terms of the Europolity, that brought it to the fore, is hence part

\footnotetext{
${ }^{72}$ Shaw 2006, in preparation.

${ }^{73}$ See the now famous Humboldt speech by German Foreign Minister Joschka Fischer in 2000 which kicked off a transnational debate (Fischer 2000).
} 
and parcel for further research on European citizenship. Another strand of research will need to explore the interpretation of the meaning of citizenship as a core constitutional norm. To that end, research programmes need to assess divergence and/or convergence in the meaning of citizenship empirically. In addition, they will need to normatively establish conditions for just and legitimate citizenship rights. The conceptual challenge lies in the controversial assessment of the Europolity as either a modern constitutional 'universe' or a contemporary 'multiverse. ${ }^{74}$ In other words, further research will need to pick up on the unintended consequences generated by the strategic introduction of citizenship expecting the input it was said to have a core principle of modern constitutionalism - to a context of beyond-the-state governance.

\section{References}

Anderson, B., 1991 (first ed. 1983), Imagined Communities, London et al.: Verso.

Beck, U./E. Grande, 2005, Das Kosmopolitische Europa, Frankfurt/M.: Suhrkamp.

Bellamy, R., 2000, Citizenship Beyond the State: The Case of Europe, O'Sullivan, N. (Hrsg.), Political Theory in Transition, London: Routledge,

Bendix, R., 1964, Nation building and citizenship, New York: John Wiley.

Benhabib, S., The Rights of Others. Aliens, Residents and Citizens, 2004, Cambridge: Cambridge University Press.

Bös, M., 2001, Die Grenzen der Europäischen Gesellschaft - Das Spannungsfeld von Territorien, Bevölkerungen und Kulturen in Europa, Kölner Zeitschrift für Soziologie und Sozialpsychologie,

Brubaker, W. R., 1992, Citizenship and Nationhood in France and Germany, Cambridge MA: Harvard University Press.

\footnotetext{
${ }^{74}$ For this argument, see especially James Tully’s work (Tully 1995).
} 
Carty, A., 1995, Interwar German Theories of International Law: The Psychoanalytical and Phenomenological Perspectives of Hans Kelsen and Carl Schmitt, Cardozo Law Review, 16, 3-4, 1235-1292.

Closa, C., 1992, The Concept of Citizenship in the Treaty of European Union, Common Market Law Review, 29, 1137-1169.

Curtin, D., 1993, The Constitutional Structure of the Union: A Europe of Bits and Pieces, Common Market Law Review, 27, 709 - 739.

Dinan, D., 1994, Ever Closer Union? An Introduction to the European Community, Boulder, CO: Lynne Rienner.

Esser, R., 2000, Historische Semantik, Lottes, G./J. Eibach (Hrsg.), Kompaß der Geschichtswissenschaft, Göttingen: Vandenhook \& Ruprecht, 281-292.

Everson, M. 1995, The Legacy of the Market Citizen, in J. Shaw and G. More (Hg) New Legal Dynamics of European Integration Oxford: Oxford University Press.

Fraser, N./A. Honneth, Redistribution or recognition?: A Political-philosophical Exchange, 2003, London ; New York: Verso.

Friese, H./P. Wagner, 2002, Survey Article: The Nascent Political Philosophy of the European Polity, Journal of Political Philosophy, 10, 3, 342-364.

Garrett, G., 1992, International Cooperation and Institutional Choice: The European Community's Internal Market, International Organization, 46, 2, 533-560.

Grande, E., 1996, Demokratische Legitimation und europäische Integration, Leviathan, 3, 339-359.

Grimm, D., 1995, Does Europe Need a Constitution?, European Law Journal, 1, 3, 282-302.

Habermas, J., 1995, Remarks on Dieter Grimm's 'Does Europe Need a Constitution?' European Law Journal, 1, 3. 
Hailbronner, K./C. Thiery, 1997, 'Schengen II and Dublin: Responsibility for Asylum Applications in Europe, Common Market Law Review, 34, 957-989.

Hobe, S., 1993, Die Unionsbürgerschaft nach dem Vertrag von Maastricht. Auf dem Weg zum Europäischen Bundesstaat?, Der Staat, 245 - 268.

Hobe, Stephan and Otto Kimminich (2004 [8th ed., 1st ed. 1975]) Einführung in das Völkerrecht. Tübingen and Basel: A. Francke Verlag.

Hobson, B., Gender and citizenship in transition, 2000, New York: Routledge.

Jenson, J., 1992, Citizenship and Equity. Variations Across Time and Space, Hiebert, J. (Hrsg.), Political Ethics: A Canadian Perspective.

---, 2005: The European Union’s Citizenship Regime: Political and Social Rights in the Era of New Governance, Vortrag auf der Tagung „Contested Meanings: Democratic Practices and Principles across Cultural Boundaries“, Queen’s University Belfast, 22.-23.9.2005, www.qub.ac.uk/polproj/reneg/workshop.htm $<20.10 .2005>$.

Joppke, C., 1998, A Challenge to the Nation-State. Immigration in Western Europe and the United States, Oxford: Oxford University Press.

Kadelbach, S., 2003, Unionsbürgerschaft, Bogdandy, A. v. (Hrsg.), Europäisches Verfassungsrecht. Theoretische und dogmatische Grundzüge, Heidelberg et al.: Springer, 539-582.

Kaplan, W., 1993, Who Belongs? Changing Concepts of Citizenship and Nationality, Kaplan, W. (Hrsg.), Belonging. The Meaning and Future of Canadian Citizenship, Montreal \& Kingston: McGill-Queen's University Press, 245-264.

Koslowski, R., 1998, European Migration Regimes: Emerging, Enlarging and Deteriorating, Journal of Ethnic and Migration Studies, 24, 4, 735-749.

Kostakopoulou, D., 2001, Citizenship, Identity and Immigration in the European Union, Manchester: Manchester University Press.

---, 2005, Ideas, Norms and European Citizenship: Explaining Institutional Change, Modern Law Review, 68, 2, 233-267. 
Kratochwil, F., 1994, Citizenship: The Border of Order, Alternatives, 19, 485 - 506.

Laffan, B., 1996, The Politics of Identity and Political Order in Europe, Journal of Common Market Studies, 34, 1, 81-102.

Lehning, P. B., 1998, European Citizenship: Between Facts and Norms, Constellations, 4, 3, 346 - 367.

Linklater, A., 1996, Citizenship and Sovereignty in the Post-Westphalian State, European Journal of International Relations, 2, 1, 77 - 103.

Magiera, S., 1991, A Citizens' Europe: Personal, Political, and Cultural Rights, Held, D./Pollitt (Hrsg.), New Forms of Democracy, London: SAGE, 153-164.

March, J. G./J. P. Olsen, 1989, Rediscovering Institutions. The Organizational Basis of Politics, New York et al.: The Free Press.

Marias, E., 1994, From Market Citizen to Union Citizen, Marias, E. (Hrsg.), European Citizenship, 1-xx.

Marshall, T. H., 1950, Citizenship and Social Class, Cambridge: Cambridge University Press.

Meehan, E., Citizenship and the European Community, 1993, London: SAGE.

---, Political Pluralism and European Citizenship, Lehning, P./A. Weale (Hrsg.), Citizenship, Democracy and Justice in the New Europe, 1997, London and New York: Routledge, 69-85.

Milliken, J., 1999, The Study of Discourse in International Relations: A Critique of Research and Methods, European Journal of International Relations, 5, 2, 225-254.

North, D. C., 1990, The path of institutional change, North, D. C. (Hrsg.), Institutions, Institutional Change and Economic Performance, Cambridge: Cambridge University Press, 92-104.

O'Leary, S., 1995, The Relationship Between Community Citizenship and the 
Protection of Fundamental Rights in Community Law, Common Market Law Review, 32, 519 - 554.

Oliveira, H. U. J. d., 1995, Union Citizenship: Pie in the Sky?, Rosas, A./E. Antola (Hrsg.), A Citizens' Europe: In Search of a New Order, London: SAGE, 58-84.

Ong, A., 2005, Flexible Staatsbürgerschaften, Frankfurt/M.: Suhrkamp.

Pierson, P., 1996, The Path to European Integration: A Historical Institutionalist Analysis., Comparative Political Studies, 29, 2, 123 - 163.

Riesenberg, P. N., 1992, Citizenship in the Western tradition : Plato to Rousseau, Chapel Hill: University of North Carolina Press.

Weldes, J./D. Saco, 1996, Making State Action Possible: The United States and the Discursive Construction of 'The Cuban Problem', 1960-1994, Millennium, 25, 2, 361395.

Scharpf, F. W., 1995, Demokratische Politik in Europa, Europäisches Zentrum für Staatswissenschaften und Staatspraxis, Discussion Paper, Nr. 4, Oktober 1995.

Shaw, J., 1997, The Many Pasts and Futures of Citizenship in the European Union, European Law Review, 22, 6, 554-572.

---, 2000, Law of the European Union, 3rd edition, Houndmills et al: Palgrave Law Masters.

---, 2006, Transforming Citizenship? The European Union, Electoral Rights and the Restructuration of European Public Space, Edinburgh: Unpubl. Manuscript (in Vorbereitung).

Snyder, F., 1990, New Directions in European Community Law. London: Weidenfeld and Nicholson.

Somers, M., 1994, Rights, Relationality, and Membership: Rethinking the Making and Meaning of Citizenship, Law and Social Inquiry, 19, 63-112.

Soysal, Y. N., 1994, The Limits of Citizenship. Migrants and Postnational 
Membership in France, Chicago: University of Chicago Press.

Tilly, C. 1995. Citizenship, Identity and Social History, 1995, Amsterdam: Cambridge University Press.

Tully, J., 1995, Strange multiplicity: constitutionalism in an age of diversity, Cambridge, New York: Cambridge University Press.

Turner, B., 1990, Outline of a Theory of Citizenship, Sociology, 24, 2, 189 - 217.

Uçarer, E. M., 2001, Managing Asylum and European Integration: Expanding Spheres of Exclusion?, International Studies Perspectives, 2, 3, 288-304.

Wallace, H., 1999, Whose Europe is it anyway? The 1998 Stein Rokkan lecture, European Journal of Political Research, 35, 287-306.

Weiler, J. H. H., 1996, European Neo-constitutionalism: in Search of Foundations for the European Constitutional Order, Bellamy, R. und D. Castiglione (Hrsg.), Constitutionalism in Transformation: European and Theoretical Approaches, Cambridge: Blackwell, 104-121.

Wiener, A., 1995, Building Institutions: Rights, Access and Belonging, Unpublished PhD Dissertation, Carleton University, Canada.

---, 1997, Making Sense of the New Geography of Citizenship - Fragmented Citizenship in the European Union, Theory and Society, 26, 4, 529-560.

---, 1998, 'European' Citizenship Practice - Building Institutions of a Non-State, Boulder, CO: Westview Press.

---, 2000, The Embedded Acquis Communautaire, Neunreither, K./A. Wiener (Hrsg.), European Integration After Amsterdam - Institutional Dynamics and Prospects for Democracy, Oxford: Oxford University Press, 318-341.

---, 2001, Zur Verfassungspolitik jenseits des Staates: Die Vermittlung von Bedeutung am Beispiel der Unionsbürgerschaft, Zeitschrift für internationale Beziehungen, 8, 1, 73-104. 
---, 2006 (in preparation), The Invisible Constitution. A Comparative Analysis of Inter-National Relations in Europe., Belfast: Unpublished Manuscript.

Wobbe, T./R. Otte, 2000, Politische Institutionen im gesellschaftlichen Wandel. Einbürgerung in Deutschland zwischen Erwartungen von Migranten und staatlicher Vorgabe, Zeitschrift für Soziologie, 29, 6, 444-462.

Wobbe, T., 2003, From Protecting to Promoting: Evolving EU Sex Equality Norms in an Organisational Field, European Law Journal, 9,1, 88-108.

Zürn, M., 1998, Regieren jenseits des Nationalstaates. Frankfurt/M.: Suhrkamp. 